\title{
Residential proximity to main roads and lung function in healthy young children
}

\section{To the Editors:}

In preschool children, exposure to traffic-related emissions is associated with increased prevalence of respiratory symptoms [1-3] and, in school-aged children, with reduced lung function growth [4]. However, to date, the association between air pollution and preschool lung function remains unclear. In a cross-sectional study, we investigated the effects of residential proximity to main roads and air pollutants on lung function in healthy preschool children.

Spirometric forced vital capacity, forced expiratory volume in $1 \mathrm{~s}$ and $0.5 \mathrm{~s}$, lung clearance index (LCI) by multiple breath washout, plethysmographic specific airway resistance (sRaw) and exhaled nitric oxide fraction $(F \mathrm{eNO})$ were measured in healthy preschool children as part of another study protocol [5]. Residential distance to the nearest main road was computed using Geographical Information System software (ArcGIS, ESRI, Redlands, CA, USA). An atmospheric dispersion model estimated the past 3 yrs exposure data for mean annual carbonaceous particulate matter with a $50 \%$ cut-off aerodynamic diameter of $10 \mu \mathrm{m}$ (PM10), nitrogen dioxide $\left(\mathrm{NO}_{2}\right)$ and nitrogen oxides $\left(\mathrm{NO}_{\mathrm{x}}\right)$. Statistical analysis was performed by MannWhitney U-tests, and simple and multiple linear regression analyses. Sample size was opportunistic and determined by the number of children recruited to the original study [5].

70 children, median (range) age 5.5 (4.1-6.9) yrs, were recruited (50\% male) to the original study [5]. Spirometric measurements were successful in 55 children, LCI and sRaw in 70 children and FeNO in 65 children. While residential distance from main roads was computed for all 70 children, past 3 yrs mean annual air pollutants data could be estimated in 51 children living within Greater London, UK.

As expected, modelled exposure to air pollution was higher in children living within $150 \mathrm{~m}$ of a main road (table 1). There was no significant difference in any of the lung function variables or FeNO according to residential proximity to main roads (table 1). Simple and multiple linear regression analyses after adjusting for age, sex, height and atopy showed no significant associations between lung function parameters and FeNO with residential distance from main roads or mean $3 \mathrm{yr}$ annual PM10, $\mathrm{NO}_{2}$ and $\mathrm{NO}_{\mathrm{x}}$ exposure.

In this cross-sectional study of healthy preschool children, we found no evidence of an association between living in proximity to a main road and lung function. It is possible that failure to show an association is related to inadequate power. However, we found no trends for reduced lung function in children living within $150 \mathrm{~m}$ of a main road. An alternative explanation is that decrements of lung growth are not the major drivers of air pollution triggered symptoms in young children who have had insufficient time for a cumulative effect of air pollution on lung function growth. In contrast, increased prevalence of clinically low lung function in adolescents living in areas of high air pollution reflects many years of a negative effect of air pollution on lung growth [4].

In conclusion, we have shown that lung function in a small cohort of healthy children at median age $5.5 \mathrm{yrs}$ is not significantly affected by living in proximity to main roads with high traffic-related air pollutants. We therefore speculate that the association between air pollution and respiratory symptoms in preschool children is perhaps due to impaired pulmonary innate immunity as suggested by animal models and not impaired lung function per se [6].

\section{S. Sonnappa*,\#, C.M. Bastardo*, P. Aurora*,\#, D. Whyatt ${ }^{\star}$, F.J. Kelly ${ }^{+}$, S.D. Beevers ${ }^{+}$and J. Grigg ${ }^{\S}$}

*Portex Unit, Respiratory Medicine and Physiology, UCL Institute of Child Health, "Dept of Respiratory Medicine, Great Ormond Street Hospital for Children NHS Trust, ${ }^{+}$MRC-HPA Centre for Environment and Health, King's College London, ${ }^{\S}$ Dept of Paediatric Respiratory and Environmental Medicine, Barts and The London School of Medicine, London, and "Lancaster Environment Centre, Lancaster University, Lancaster, UK.

Correspondence: S. Sonnappa, Portex Unit, Respiratory Medicine and Physiology, UCL Institute of Child Health and Great

\begin{tabular}{|c|c|c|c|c|}
\hline \multirow{2}{*}{$\begin{array}{l}\text { TABLE } 1 \\
\text { Variables }\end{array}$} & \multicolumn{4}{|c|}{$\begin{array}{l}\text { Lung function, exhaled nitric oxide fraction } \\
\text { (FeNO) and modelled exposure to air pollutants } \\
\text { according to residential proximity to main roads }\end{array}$} \\
\hline & $\leqslant 150 \mathrm{~m}^{\#}$ & $\geqslant 150 \mathrm{~m}^{\circ}$ & $\begin{array}{l}\text { Mean difference } \\
\qquad(95 \% \mathrm{Cl})\end{array}$ & p-value \\
\hline FVC z score & $0.42 \pm 0.88$ & $0.42 \pm 1.11$ & $0.00(-0.55-0.55)$ & 0.99 \\
\hline FEV1 z score & $0.31 \pm 0.89$ & $-0.14 \pm 0$ & $0.45(-0$ & 0.09 \\
\hline FEV 1 :FVC z score & $-0.76 \pm 0.74$ & $-0.89 \pm 0.86$ & $0.13(-0.3$ & 0.58 \\
\hline FEV0.5 z score & $-1.03 \pm 0.82$ & $-1.08 \pm 1.12$ & $0.05(-0.49-0.60)$ & 0.84 \\
\hline LCI & $6.7 \pm 0.5$ & $6.6 \pm 0.5$ & $0.1(-0.2$ & 0.53 \\
\hline sRaw kPa.s & $1.05 \pm 0.22$ & $1.06 \pm 0.19$ & $0.01(-0.10-0.09)$ & 0.91 \\
\hline FeNO ppb & $5.4 \pm 4.3$ & $5.4 \pm 5$ & .4) & 0.99 \\
\hline $\mathrm{PM} 10 \mu \mathrm{g} \cdot \mathrm{m}^{-3}$ & $24.0 \pm 1.1$ & $23.3 \pm 0.8$ & $0.7(0.1-1.2)$ & 0.02 \\
\hline $\mathrm{NO}_{2} \mu \mathrm{g} \cdot \mathrm{m}^{-3}$ & $45.4 \pm 7.3$ & $41.5 \pm 5.4$ & $3.9(0.2-7.5)$ & 0.04 \\
\hline $\mathrm{NO}_{x} \mu \mathrm{g} \cdot \mathrm{m}^{-3}$ & $83.4 \pm 19.8$ & $72.2 \pm 14.5$ & $11.2(1.3-21.0)$ & 0.03 \\
\hline \multicolumn{5}{|c|}{ 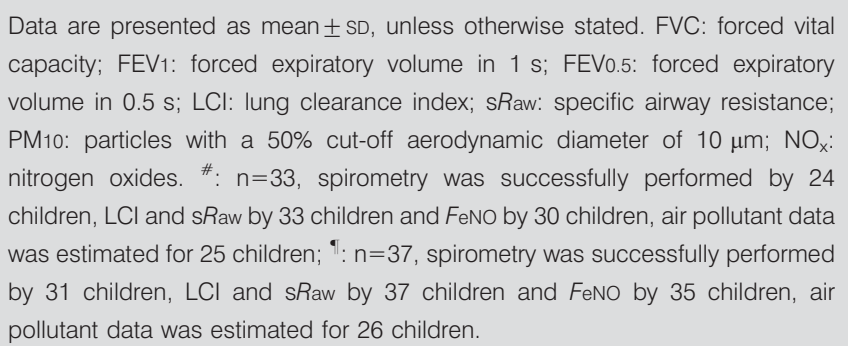 } \\
\hline
\end{tabular}


Ormond Street Hospital for Children, 30 Guilford Street, London, WC1N 1EH, UK. E-mail: s.sonnappa@ich.ucl.ac.uk

Support Statement: This study was supported by Asthma UK, Smiths Medical and the European Respiratory Society.

Statement of Interest: A statement of interest for the study itself can be found at www.erj.ersjournals.com/site/misc/state ments.xhtml

\section{REFERENCES}

1 Pierse N, Rushton L, Harris RS, et al. Locally generated particulate pollution and respiratory symptoms in young children. Thorax 2006; 61: 216-220.
2 Andersen ZJ, Loft S, Ketzel M, et al. Ambient air pollution triggers wheezing symptoms in infants. Thorax 2008; 63: 710-716.

3 Nordling E, Berglind N, Melen E, et al. Traffic-related air pollution and childhood respiratory symptoms, function and allergies. Epidemiology 2008; 19: 401-408.

4 Gauderman WJ, Vora H, McConnell R, et al. Effect of exposure to traffic on lung development from 10 to 18 years of age: a cohort study. Lancet 2007; 369: 571-577.

5 Sonnappa S, Bastardo CM, Wade A, et al. Symptom-pattern phenotype and pulmonary function in preschool wheezers. J Allergy Clin Immunol 2010; 126: 519-526.

6 Gowdy K, Krantz QT, Daniels M, et al. Modulation of pulmonary inflammatory responses and antimicrobial defenses in mice exposed to diesel exhaust. Toxicol Appl Pharmacol 2008; 229: 310-319.

DOI: 10.1183/09031936.00181910

\section{Severe hypersensitivity reaction as acute eosinophilic pneumonia and skin eruption induced by proguanil}

\section{To the Editors:}

The combination of atovaquone and proguanil is effective and safe in the prevention and treatment of malaria. We present the first report of proguanil-induced acute eosinophilic pneumonia (AEP) associated with skin eruption. On December 18, 2006, a 40-yr-old female was admitted to our hospital (Victor Provo Medical Centre, Roubaix, France) for shortness of breath and widespread skin lesions. She had a 10-pack-yr smoking history but no respiratory illness or relevant comorbidity. On the morning of December 8, 2006, she had initiated atovaquone-proguanil treatment for malaria prophylaxis prior to a trip to Senegal. She had taken the same treatment for the first time 1 yr previously without any complications. That evening she developed progressive dyspnoea with nonproductive cough and subacute fever $\left(38^{\circ} \mathrm{C}\right)$. She only stayed in Senegal for 4 days and did not leave her hotel room during this time. After returning to France she continued to take atovaquoneproguanil for 1 week. Increased shortness of breath prompted her to consult her general practitioner, who prescribed amoxicillin plus clavulanic acid for bronchitis. This treatment was withdrawn on the day 4 because of rapidly spreading skin eruptions on day 3. Although amoxicillin plus clavulanic acid was then replaced by telithromycin, the respiratory and skin symptoms worsened and the patient was referred to our hospital.

Physical examination revealed a widespread non-pruritic maculopapular eruption, without Nikolsky sign or mucosal involvement (fig. 1a). The patient was tachypnoeic with diffuse inspiratory crackles. The superficial lymph nodes were not enlarged. A chest radiograph showed subtle, diffuse, reticulonodular opacities. High-resolution computed tomography revealed a bilateral ground-glass pattern with non-specific consolidations and linear opacities (fig. 1b). Arterial blood gas analysis (with room air) revealed oxygen tension of $68 \mathrm{mmHg}$, carbon dioxide tension of $32 \mathrm{mmHg}$ and oxygen saturation of $94 \%$. The white blood cell count on admission was $26 \times$ $10^{3}$ cells $\cdot \mathrm{mm}^{-3}$ with $11 \%$ eosinophils $\left(2.9 \times 10^{3}\right.$ cells $\left.\cdot \mathrm{mm}^{-3}\right)$. The C-reactive protein level was $136 \mathrm{mg} \cdot \mathrm{L}^{-1}$. Total serum immunoglobulin (Ig)E was $37,210 \mathrm{kU} \cdot \mathrm{L}^{-1}$. Tests for various pulmonary pathogens (Strongoloides stercoralis, Toxocara canis, Ascaris lumbricoides and Tricheinella spiralis), a urine analysis and stool tests for ova and parasites were negative. Antinuclear antibody, rheumatoid factor and HIV blood tests were all negative. On day 4 the leukocyte count peaked at $28 \times 10^{3}$ cells $\cdot \mathrm{mm}^{-3}$ ( $39 \%$ eosinophils). The patient underwent fibreoptic bronchoscopy on day 4. Bronchoalveolar lavage (BAL) showed an abundance of eosinophils: total cell count 780,000 cells $\cdot \mathrm{mL}^{-1}$; macrophages $67 \%$; lymphocytes $2 \%$; neutrophils $3 \%$; and eosinophils $28 \%$. Blood and BAL cultures were negative. A skin biopsy revealed minor cell infiltration, composed mostly of lymphocytes with some eosinophils, without vasculitis. The direct immunofluorescence assays were negative.

A drug-induced AEP was suspected and atovaquone-proguanil was withdrawn soon after hospitalisation. The patient recovered within 1 week with no need for prednisolone therapy. 2 months later, prick, intradermal and patch tests (with 30\% drug diluted in a petrolatum base) were performed according to a previously published method [1]. The patch was removed after $48 \mathrm{~h}$ and the tests were scored at 48 and $72 \mathrm{~h}$ and 8 days, according to the International Contact Dermatitis Group system [1]. Drug provocation tests and immediate and late prick, intradermal and patch skin tests for amoxicillin, ceftriaxione, erythromycin and telithromycin were negative. The patient had a doubtful skin-prick test result for atovaquone-proguanil. The patch test results for antimalarial drugs (all negative in controls) are presented in table 1. The 48- and 72-h late readings showed a strong positive reaction for atovaquone-proguanil and proguanil alone, but not atovaquone (fig. 1c). 